10.2478/v10103-011-0016-0

\title{
Foreign Direct Investment and Sustainable Development in the New EU Member States: Environmental Aspects
}

\begin{abstract}
The aim of this paper is to examine the potential impact of foreign investors' activities on the environment of the new European Union's Member States and discuss a role of a common environmental policy and member states' policies towards foreign investors. The analysis embraces three new EU countries, namely the Czech Republic, Poland and Slovakia. The scope of the analysis are years 1997-2007. The subject of the analysis is the sector and branch structure of FDI stock in the new EU Member States with special reference to FDI located in pollution-intensive industries which are selected according to the UNCTAD classification. Both the OECD and national data base of statistics is used to calculate the share of foreign investors' involvement in pollution-intensive activities in the new UE Member States. The research results show that as yet there has been no empirical evidence that FDI has a particularly negative impact on the natural environment in the new EU Member States.
\end{abstract}

\section{Introduction}

The impact of foreign direct investment (FDI) on recipient countries' economies is a subject of in-depth analyses. Environmental and social aspects of foreign investors' activities are less recognized although they are of great

\footnotetext{
${ }^{*}$ Ph. D., Full Professor at the University of Łódź
} 
importance for the sustainable development of host countries. As far as environmental aspects are concerned, FDI can either upgrade the environment of these countries or be a distorting factor. The final result depends on a balance of macro and micro factors (UNCTAD 1999, pp. 289-312).

At a macro level, apart from environment protection regulations and their enforcement, the impact of FDI on the environment of the host countries is determined by the sector/branch structure of FDI involved in a given country and especially by the extent to which it is located in pollution-intensive industries. At a micro-level, management methods and types of technology used in foreign affiliates of transnational corporations are crucial for environmental issues.

The aim of this paper is to examine the potential impact of foreign investors' activities on the environment of the new European Union's Member States and discuss a role of a common environmental policy and member states' policies towards foreign investors. The detailed research tasks are as follows:

- to present theoretical findings and on environmental aspects of foreign direct investors' activities, especially in less developed countries and in countries in transition

- to show hitherto empirical evidence on the impact of FDI on the environment of recipient countries

- to calculate a share of FDI in pollution-intensive activities in the new EU Member States and analyze changes in this area

- to evaluate a potential impact of FDI on the environment in the new EU Member States

- to discuss a role of the EU environmental policy and national policies towards foreign investors in changing their attitude towards environmental issues.

As far as a method of research is concerned, the UNCTAD classification of potentially highly polluting industries will be used. Both the OECD and national data base of statistics will be used to calculate the share of foreign investors' involvement in pollution-intensive activities in the new UE Member States. However, some limitations in the proposed research can appear. They are related to the scope of the planned research and to lack of detailed statistical data on branch structure of FDI in the new EU Member states. 


\section{FDI and the Environment - Theoretical Aspects and the Hitherto Empirical Evidence}

The issue of the impact of FDI on the environment stirs essential controversies (Gentry 1999 pp. 21-45; Zarsky 1999, pp. 47-73).

FDI is perceived as a potential burden for or an outright threat to the environment, especially in less developed countries, because it entails the use of land and raw materials and contributes to growth of consumption in host countries. By introducing new products into the market, foreign investors' activity may also contribute to a change in the consumption patterns in the host country in the direction of burdening the environment. Furthermore, the gap in the environment protection standards between developed and developing economies may contribute to the creation of the so-called 'pollution havens', because it encourages the transfer of 'dirty' industries to countries with lower environment protection norms. There may also arise a problem of the so-called 'cascading pollution havens' when a firm contracts its 'dirty' production processes with other enterprises so as to make an impression of being environmental-friendly (OECD 1999, p.14). Close to the 'pollution havens' hypothesis is that of the 'regulatory chill' (Fortanier, Maher 2001, p.5). It means that 'countries refrain from enacting stricter environmental standards in response to fears of losing a competitive edge against other countries in obtaining FDI' (Gray 2002, p. 310).

However, according to the other group of views, FDI contributes to improvement in the state of the environment, because the investing firms coming mainly from the OECD countries possess more advanced and cleaner technologies than the firms in the less developed host countries. Thus FDI leads to improvement in efficiency and transfer of know-how in the area of management. As a result, the environment protection level in the host country is raised by bringing the protection norms closer to the standards binding in developed countries (the "pollution halo" effect). Foreign investors' activity may also find its reflection in environmentally favorable changes in the consumption patterns.

The research - scare as it is- allows to surmise that FDI generates both positive and negative environmental effects (Budnikowski 1998, pp. 89-98, Gentry 1999, pp.21-45, Zarsky 1999, pp.47-73, Goldenman 1999, pp. 75-91, Witkowska 2002, pp. 297-310), Wysokińska, Witkowska 2004, pp. 69-86). The balance sheet of these influences is dependent on the characteristics of the investor, the sectoral structure of investments and their geographical location. The empirical verification of the extreme hypotheses on the impact of FDI on the environment encounters methodological difficulties and lack of data. 
Some research related to the discussed problem was carried out in the 90ies. and at the beginning of the $21^{\text {st }}$ century. However, empirical evidence is varied (Petrovic-Randjelovic 2007, pp. 183-190).

According to (OECD 1997), most pollution intensive FDI flew from developed countries to developed countries, rather than to developing ones.

The analysis related to the USA (Kolstad and Xing, 1998) confirmed a correlation between lax environmental regulations in host countries and FDI inflows into pollution-intensive industries in the late 90ies. It was the case of investment coming from the US chemical industry and located in countries with less stringent environmental regulations.

Research related to Central and Eastern Europe and former Soviet Republics (Smarzynska and Wei, 2001) in which firm-level data were used does not confirm the existence of 'pollution havens' in these countries.

\section{FDI in Pollution-Intensive Activities in the New EU Member States. The Cases of the Czech Republic, Poland and Slovakia}

The analysis in this paper embraces three new EU countries, namely the Czech Republic, Poland and Slovakia. The scope of the analysis are years 19972007. The subject of the analysis is the sector and branch structure of FDI stock in the new EU Member States with special reference to FDI located in pollutionintensive industries. The manufacturing industries perceived as potentially highly polluting are: mining and quarrying, wood, publishing and printing, refined petroleum \& other treatments, chemical products, rubber and plastic products and metal products. Some services regarded as more burdensome for the environment are: hotels, restaurants and transport.

OECD data base is used for calculations of the rate of inward FDI stock located in the pollution-intensive manufacturing industries and services in these three countries before and after the membership of the EU. The average rate for the EU27 is calculated on the basis of Eurostat data (Report London Economics 2009, p. 56).

Author's research shows that:

- The three analyzed countries have no large foreign direct investment in the extractive industries which often cause irreversible consequences for the environment $(0.2 \%$ in the case of Poland and $1.3 \%$ in Slovakia and $2.8 \%$ in the Czech Republic), (see Tables 1-3).

- The shares of inward FDI stock located in so-called dirty industries in the total FDI stock in these countries are higher than the average for the EU27, 
(see Tables 1-3 and Table 4). In 2006, this share amounted to $9.3 \%$ in the EU27, $13.6 \%$ in the case of Poland, $14.5 \%$ in the Czech Republic and 22.5\% in Slovakia. In 2007, the share increased by about 0.5 and 1 percentage point in Poland and the Czech Republic respectively in comparison to the previous year. The calculated shares could be underestimated because the available data base do not embrace some polluting industries such as mineral products and leather industries.

- The above discussed shares have been changing in the analyzed countries during the pre- and post-accession period. The share rose in Poland slightly (from 13.2\% in 1997 to $14.1 \%$ in 2007) and in Slovakia more evidently (from $17.3 \%$ in 1998 to $22.5 \%$ in 2006) while it fell in the Czech Republic (from $16.8 \%$ in 1997 to $15.4 \%$ in 2007). It is worth noting that the shares fluctuated in the analyzed period.

- A tendency towards a growing share of inward FDI in services in the total inward FDI stock was observed in the Czech Republic and Poland in 20032008 ( see Tables 5-7). After accession of these countries to the EU the share of services in the total FDI stock was increasing and surpassed 50\%. In Slovakia, this share decreased by 6 percentage points in 2004-2006 and amounted to $40.2 \%$.

- FDI in services, however, does not constitute a major burden for the environment. Foreign investors show higher interest in professional services in the analyzed countries such as financial intermediation, real estate, renting and business activities than in services regarded as more burdensome for the environment, i.e. in transport, hotels and restaurants. The FDI stock located in hotels and restaurants, in land and air transport accounted for 1.2 $\%$ of the total FDI stock in Poland, 1\% in the Czech Republic in 2008 and 0.9 in Slovakia in 2006 (see tables 5-7). These shares were decreasing in the case of Poland and the Czech Republic and were stable in Slovakia.

\section{A Role of the EU Environmental Policy and National Policies Towards Foreign Investors in Changing their Attitude Towards Environmental Issues}

The new EU Member States inherited from the communist system economic structures that caused huge environmental damage in their economies. After the systemic transformation all the analyzed countries introduced national environmental policies aimed at improving a difficult situation in this field. Nevertheless, at the moment of joining the EU these countries were not able to fulfill demanding accession conditions in the area of the environment. All the 
analyzed countries received transition periods related to some EU environmental requirement. Adjustments to these requirements will be connected with an enormous financial effort in the new Member States ${ }^{1}$. These countries continue to implement the EU environmental law. As a consequence environmental regulations in these countries are stricter than previously and apply both to domestic and foreign firms.

Transnational corporations can set up foreign affiliates that operate abroad at corporate environmental standards as well. The EU strong environmental requirements can be treated as a barrier to potential practices of seeking some kind of pollution havens in those countries.

Apart from that the new EU Member States carry out own national autonomous policies towards foreign investors using rich packages of incentives. In this way, the analyzed countries try to influence investment decisions and encourage investors for investing in industries constituting knowledge-based economy. Additionally, some countries, for example Poland, support investment introducing modern, environmentally-friendly technologies (Witkowska 2007).

The change of economies' structures of the new EU countries would decrease the share of FDI stock in pollution -intensive industries in the total FDI stock. The presence of FDI in pollution-intensive industries is, however, only one of the factors influencing the environment in a host country. Technologies used by investors and environment management play an important role as well.

\section{Conclusion}

- The changes in the sector and branch structure of inward FDI stock in the new EU Member States after their accession to the EU, as evaluated from the environmental point of view, have not been far-reaching. The expectation of reducing the share of FDI in potentially polluting industries in the total inward FDI stock could be fulfilled if the overall manufacturing structure of these countries is shifted towards more modern and high- tech industries.

- According to the stage of economic development of the new EU Member countries and their locational advantages, investors locate part of their

\footnotetext{
${ }^{1}$ Costs of implementation of the EU environmental rules are estimated on about $€ 30$ billion in Poland during the next $10-15$ years.
} 
investment in industries in which a production process require using specific technologies. They in turn are burden for the environment.

- Taking into account the fact that the new EU Member States should accept and introduce strict environmental rules legally binding in the EU as a whole, activities of foreign investors in these countries should not be treated as creation of pollution havens.

- The results of the conducted analysis allow to conclude that as yet there has been no empirical evidence that FDI has a particularly negative impact on the natural environment in the new EU Member States. 
Table 1. Foreign direct investment stock in pollution-intensive industries in the new EU Member States - The Czech Republic, 1997-2007, USD Million, Percentage of total inward FDI stock

\begin{tabular}{|c|c|c|c|c|c|c|c|c|c|c|c|c|}
\hline \multirow[b]{2}{*}{ Specification } & \multicolumn{2}{|c|}{1997} & \multicolumn{2}{|c|}{2000} & \multicolumn{2}{|c|}{2004} & \multicolumn{2}{|c|}{2005} & \multicolumn{2}{|c|}{2006} & \multicolumn{2}{|c|}{2007} \\
\hline & $\begin{array}{c}\text { USD } \\
\text { Million }\end{array}$ & $\%$ & $\begin{array}{c}\text { USD } \\
\text { Million }\end{array}$ & $\%$ & $\begin{array}{c}\text { USD } \\
\text { Million }\end{array}$ & $\%$ & $\begin{array}{c}\text { USD } \\
\text { Million }\end{array}$ & $\%$ & $\begin{array}{c}\text { USD } \\
\text { Million }\end{array}$ & $\%$ & $\begin{array}{c}\text { USD } \\
\text { Million }\end{array}$ & $\%$ \\
\hline $\begin{array}{l}\text { 1495: MINING AND } \\
\text { QUARRYING }\end{array}$ & 79.8 & 0.9 & 400.7 & 1.9 & 730.4 & 1.3 & 252.0 & 0.4 & 1964.0 & 2.5 & 3121.4 & 2.8 \\
\hline $\begin{array}{l}\text { 1100: Extraction of } \\
\text { crude petroleum and } \\
\text { natural gas; service } \\
\text { activities incidental } \\
\text { to oil and gas } \\
\text { extraction, excluding } \\
\text { surveying }\end{array}$ & 0.5 & 0.01 & 0.0 & 0.0 & $159 ., 9$ & 0.3 & 17.0 & 0.03 & 3.3 & 0.004 & 304.4 & 0.3 \\
\hline $\begin{array}{l}\text { 2205: Wood, } \\
\text { publishing and } \\
\text { printing }\end{array}$ & 417.1 & 4.5 & 669.9 & 3.1 & 1876.7 & 3.3 & 1743.1 & 2.9 & 2045.9 & 2.6 & 2472.7 & 2.2 \\
\hline $\begin{array}{l}\text { 2300: Refined } \\
\text { petroleum \& other } \\
\text { treatments }\end{array}$ & 183.9 & 2.0 & 232.3 & 1.1 & 361.5 & 0.6 & 384.2 & 0.6 & 434.9 & 0.5 & 557.4 & 0.5 \\
\hline
\end{tabular}




\begin{tabular}{|c|c|c|c|c|c|c|c|c|c|c|c|c|}
\hline $\begin{array}{l}\text { 2400: Chemical } \\
\text { products }\end{array}$ & 304.0 & 3.3 & 675.0 & 3.1 & 1506.7 & 2.6 & 1579.4 & 2.6 & 1845.8 & 2.3 & 2888.7 & 2.6 \\
\hline $\begin{array}{l}\text { 2500: Rubber and } \\
\text { plastic products }\end{array}$ & 186.7 & 2.0 & 508.0 & 2.3 & 1526.3 & 2.7 & 1472.6 & 2.4 & 2277.4 & 2.9 & 2539.8 & 2.3 \\
\hline 2805: Metal products & 380.9 & 4.1 & 781.5 & 3.6 & 3062.9 & 5.3 & 2922.5 & 4.8 & 3001.5 & 3.8 & 5375.5 & 4.9 \\
\hline $\begin{array}{l}\text { Total FDI stock in } \\
\text { pollution intensive } \\
\text { industries }\end{array}$ & 1472.6 & 16.8 & 3267.4 & 15.1 & 9064.5 & 15.8 & 8353.8 & 13.8 & 11569.5 & 14.5 & 16955.5 & 15.4 \\
\hline TOTAL FDI STOCK & 9233.2 & 100.0 & 21646.9 & 100.0 & 57255.3 & 100.0 & 60661.9 & 100.0 & 79841.1 & 100.0 & 110094.5 & 100.0 \\
\hline
\end{tabular}

Source: OECD and own calculations. 
Table 2. Foreign direct investment stock in pollution-intensive industries in the new EU Member States - Poland, 1997-2007, USD Million, Percentage of total inward FDI stock

\begin{tabular}{|c|c|c|c|c|c|c|c|c|c|c|c|c|}
\hline \multirow[b]{2}{*}{ Specification } & \multicolumn{2}{|c|}{1997} & \multicolumn{2}{|c|}{2000} & \multicolumn{2}{|c|}{2004} & \multicolumn{2}{|c|}{2005} & \multicolumn{2}{|c|}{2006} & \multicolumn{2}{|c|}{2007} \\
\hline & $\begin{array}{c}\text { USD } \\
\text { Million }\end{array}$ & $\%$ & $\begin{array}{c}\text { USD } \\
\text { Million }\end{array}$ & $\%$ & $\begin{array}{c}\text { USD } \\
\text { Million }\end{array}$ & $\%$ & $\begin{array}{c}\text { USD } \\
\text { Million }\end{array}$ & $\%$ & $\begin{array}{c}\text { USD } \\
\text { Million }\end{array}$ & $\%$ & $\begin{array}{c}\text { USD } \\
\text { Million }\end{array}$ & $\%$ \\
\hline $\begin{array}{l}\text { 1495: MINING AND } \\
\text { QUARRYING }\end{array}$ & 44.9 & 0.3 & 138.2 & 0.4 & 202.2 & 0.2 & 112.2 & 0.1 & 167.8 & 0.1 & 326.5 & 0.2 \\
\hline $\begin{array}{l}\text { 1100: Extraction of } \\
\text { crude petroleum and } \\
\text { natural gas; service } \\
\text { activities incidental to } \\
\text { oil and gas extraction, } \\
\text { excluding surveying }\end{array}$ & 6.3 & 0.04 & 6.8 & 0.02 & 81.6 & 0.1 & 12.8 & 0.01 & 38.5 & 0.03 & 142.7 & 0.1 \\
\hline $\begin{array}{l}\text { 2205: Wood, } \\
\text { publishing and } \\
\text { printing }\end{array}$ & 594.0 & 4.1 & 1501.1 & 4.4 & 3724.7 & 4.3 & 3567.2 & 3.9 & 4577.6 & 3.6 & 6276.8 & 3.6 \\
\hline $\begin{array}{l}\text { 2300: Refined } \\
\text { petroleum \& other } \\
\text { treatments }\end{array}$ & 3.8 & 0.03 & 21.3 & 0.06 & 82.5 & 0.1 & 86.5 & 0.01 & 125.2 & 0.1 & 141.9 & 0.1 \\
\hline
\end{tabular}




\begin{tabular}{|c|c|c|c|c|c|c|c|c|c|c|c|c|}
\hline $\begin{array}{l}\text { 2400: Chemical } \\
\text { products }\end{array}$ & 598.3 & 4.1 & 1399.5 & 4.1 & 3179.0 & 3.7 & 3057.2 & 3.4 & 4095.6 & 3.3 & 5357.3 & 3.0 \\
\hline $\begin{array}{l}\text { 2500: Rubber and } \\
\text { plastic products }\end{array}$ & 372.8 & 2.6 & 808.8 & 2.4 & 2286.6 & 2.6 & 2521.0 & 2.8 & 3544.6 & 2.8 & 4294.9 & 2.4 \\
\hline 2805: Metal products & 312.5 & 2.1 & 672.1 & 2.0 & 2795.8 & 3.2 & 3054.1 & 3.4 & 4548.3 & 3.6 & 8445.0 & 4.8 \\
\hline $\begin{array}{l}\text { Total FDI stock in } \\
\text { pollution intensive } \\
\text { industries }\end{array}$ & 1926.3 & 13.2 & 4541.0 & 13.3 & 12270.8 & 14.2 & 12398.2 & 13.7 & 17059.1 & 13.6 & 24842.4 & 14.1 \\
\hline TOTAL FDI STOCK & 14587.2 & 100.0 & 34226.8 & 100.0 & 86634.3 & 100.0 & 90751.9 & 100.0 & 125596.8 & 100.0 & 175850.7 & 100.0 \\
\hline
\end{tabular}

Source: OECD and own calculations. 
Table 3. Foreign direct investment stock in pollution-intensive industries in the new EU Member States - Slovakia, 1997-2007, USD Million, Percentage of total inward FDI stock

\begin{tabular}{|c|c|c|c|c|c|c|c|c|c|c|c|c|}
\hline \multirow[b]{2}{*}{ Specification } & \multicolumn{2}{|c|}{1998} & \multicolumn{2}{|c|}{2000} & \multicolumn{2}{|c|}{2004} & \multicolumn{2}{|c|}{2005} & \multicolumn{2}{|c|}{2006} & \multicolumn{2}{|c|}{2007} \\
\hline & $\begin{array}{c}\text { USD } \\
\text { million }\end{array}$ & $\%$ & $\begin{array}{c}\text { USD } \\
\text { million }\end{array}$ & $\%$ & $\begin{array}{c}\text { USD } \\
\text { million }\end{array}$ & $\%$ & $\begin{array}{c}\text { USD } \\
\text { million }\end{array}$ & $\%$ & $\begin{array}{c}\text { USD } \\
\text { million }\end{array}$ & $\%$ & $\begin{array}{c}\text { USD } \\
\text { million }\end{array}$ & $\%$ \\
\hline $\begin{array}{l}\text { 1495: MINING AND } \\
\text { QUARRYING }\end{array}$ & 20.3 & 0.8 & 27.7 & 0.6 & 124.4 & 0.6 & 122.8 & 0.5 & 449.9 & 1.3 & - & - \\
\hline $\begin{array}{l}\text { 1100: Extraction of } \\
\text { crude petroleum and } \\
\text { natural gas; service } \\
\text { activities incidental } \\
\text { to oil and gas } \\
\text { extraction, excluding } \\
\text { surveying }\end{array}$ & 20.0 & 0.8 & 24.6 & 0.5 & 87.6 & 0.4 & 88.7 & 0.4 & 389.1 & 1.2 & - & - \\
\hline $\begin{array}{l}\text { 2205: Wood, } \\
\text { publishing and } \\
\text { printing }\end{array}$ & 20.3 & 0.8 & 143.2 & 3.2 & 404.0 & 1.8 & 2091.5 & 8.8 & 625.2 & 1.9 & - & - \\
\hline
\end{tabular}




\begin{tabular}{|c|c|c|c|c|c|c|c|c|c|c|c|c|}
\hline $\begin{array}{l}\text { 2300: Refined } \\
\text { petroleum \& other } \\
\text { treatments }\end{array}$ & 49.3 & 2.0 & 158.2 & 3.5 & 1593.0 & 7.3 & 1330.5 & 5.6 & 1727.4 & 5.1 & - & - \\
\hline $\begin{array}{l}\text { 2400: Chemical } \\
\text { products }\end{array}$ & 90.7 & 3.6 & 110.2 & 2.4 & 488.4 & 2.2 & 397.1 & 1.7 & 822.9 & 2.4 & - & - \\
\hline $\begin{array}{l}\text { 2500: Rubber and } \\
\text { plastic products }\end{array}$ & 14.4 & 0.6 & 33.3 & 0.7 & 368.2 & 1.7 & 336.7 & 1.4 & 336.7 & 1.4 & - & - \\
\hline 2805: Metal products & 238.0 & 9.5 & 799.8 & 17.8 & 2402.3 & 11.0 & 2206.0 & 9.3 & 2206.0 & 10.3 & - & - \\
\hline $\begin{array}{l}\text { Total FDI stock in } \\
\text { pollution intensive } \\
\text { industries }\end{array}$ & 433.0 & 17.3 & 1272.4 & 28.3 & 5380.3 & 24.6 & 6484.6 & 27.4 & 7579.1 & 22.5 & - & - \\
\hline TOTAL FDI STOCK & 2499.2 & 100.0 & 4503.0 & 100.0 & 21880.8 & 100.0 & 23655.3 & 100.0 & 23655.3 & 100.0 & 40702.1 & 100.0 \\
\hline
\end{tabular}

Source: OECD and own calculations. 
Table 4. Foreign direct investment stock in pollution-intensive industries in EU27, 2006, (Percentage of total inward FDI stock)

\begin{tabular}{|c|c|c|c|}
\hline \multirow{2}{*}{ Specification } & $\begin{array}{c}\text { FDI originating } \\
\text { from EU27 }\end{array}$ & $\begin{array}{l}\text { FDI originating } \\
\text { from non-EU27 }\end{array}$ & Total \\
\hline & $\%$ & $\%$ & $\%$ \\
\hline $\begin{array}{l}\text { MINING AND } \\
\text { QUARRYING }\end{array}$ & 2.9 & 2.5 & 2.8 \\
\hline $\begin{array}{l}\text { Wood, publishing and } \\
\text { printing }\end{array}$ & 0.8 & 1.6 & 1.0 \\
\hline $\begin{array}{l}\text { Refined petroleum \& } \\
\text { other treatments }\end{array}$ & 0.7 & 0.8 & 0.7 \\
\hline Chemical products & 2.9 & 3.9 & 3.2 \\
\hline $\begin{array}{l}\text { Rubber and plastic } \\
\text { products }\end{array}$ & 0.7 & 0.4 & 0.6 \\
\hline Metal products & 1.0 & 0.8 & 1.0 \\
\hline $\begin{array}{l}\text { Total FDI stock in } \\
\text { pollution intensive } \\
\text { industries }\end{array}$ & 9.0 & 10.0 & 9.3 \\
\hline TOTAL FDI STOCK & 100.0 & 100.0 & 100.0 \\
\hline
\end{tabular}

Source: Report London Economics, 4 November 2009, p. 56. 
Table 5. FDI stock in pollution-intensive services in Poland, 2003-2009, USD Billion, \%

\begin{tabular}{|c|c|c|c|c|c|c|c|c|c|c|c|c|}
\hline \multirow[b]{2}{*}{ Specification } & \multicolumn{2}{|c|}{2003} & \multicolumn{2}{|c|}{2004} & \multicolumn{2}{|c|}{2005} & \multicolumn{2}{|c|}{2006} & \multicolumn{2}{|c|}{2007} & \multicolumn{2}{|c|}{2008} \\
\hline & $\begin{array}{c}\text { USD } \\
\text { Billion }\end{array}$ & $\%$ & $\begin{array}{c}\text { USD } \\
\text { Billion }\end{array}$ & $\%$ & $\begin{array}{c}\text { USD } \\
\text { Billion }\end{array}$ & $\%$ & $\begin{array}{c}\text { USD } \\
\text { Billion }\end{array}$ & $\%$ & $\begin{array}{c}\text { USD } \\
\text { Billion }\end{array}$ & $\%$ & $\begin{array}{c}\text { USD } \\
\text { Bllion }\end{array}$ & $\%$ \\
\hline Total FDI stock & $\mathbf{5 7 . 8}$ & 100.0 & 86.6 & 100.0 & 90.8 & 100.0 & 125.6 & 100.0 & 178.2 & 100.0 & 163.0 & 100.0 \\
\hline Total FDI stock in services & 33.7 & 58.2 & 48.6 & 56.1 & 51.8 & $\mathbf{5 7 . 0}$ & 74.2 & 59.1 & 104.9 & 58.9 & 98.4 & 60.3 \\
\hline $\begin{array}{l}\text { FDI stock in pollution- } \\
\text { intensive services } \\
\text { a) }\end{array}$ & 1.9 & 3.3 & 1.8 & 2.0 & 1.8 & 1.95 & 2.17 & 1.7 & 2.85 & 1.6 & 1.92 & 1.2 \\
\hline
\end{tabular}

a) Hotels and restaurants, land and air transport.

Source: The OECD data base and own calculations. 
Table 6. FDI stock in pollution-intensive services in the Czech republic 2003-2008, USD Billion, \%

\begin{tabular}{|c|c|c|c|c|c|c|c|c|c|c|c|c|}
\hline \multirow[t]{2}{*}{ Specification } & \multicolumn{2}{|c|}{2003} & \multicolumn{2}{|c|}{2004} & \multicolumn{2}{|c|}{2005} & \multicolumn{2}{|c|}{2006} & \multicolumn{2}{|c|}{2007} & \multicolumn{2}{|c|}{2008} \\
\hline & USD & $\%$ & USD & $\%$ & USD & $\%$ & USD & $\%$ & USD & $\%$ & USD & $\%$ \\
\hline Total FDI stock & 45.3 & 100.0 & 57.3 & 100.0 & 60.7 & 100.0 & 40.6 & 50.8 & 56.6 & 50.4 & 110.6 & 100.0 \\
\hline Total FDI stock in services & 21.5 & 47.4 & 28.5 & 49.9 & 33.0 & 54.5 & 0.7 & 0.8 & 1.3 & 1.2 & 58.9 & 53.2 \\
\hline $\begin{array}{l}\text { FDI stock in pollution- } \\
\text { intensive services } \\
\text { a) }\end{array}$ & 1.7 & 3.8 & 2.0 & 3.4 & 1.8 & 2.9 & 40.6 & 50.8 & 56.6 & 50.4 & 1.2 & 1.0 \\
\hline
\end{tabular}

a) Hotels and restaurants, land and air transport.

Source. The OECD data base and own calculations. 
Table 7. FDI stock in pollution-intensive services in Slovakia, 2003-2008, USD Billion, \%

\begin{tabular}{|c|c|c|c|c|c|c|c|c|c|c|c|c|}
\hline \multirow[t]{2}{*}{ Specification } & \multicolumn{2}{|c|}{2003} & \multicolumn{2}{|c|}{2004} & \multicolumn{2}{|c|}{2005} & \multicolumn{2}{|c|}{2006} & \multicolumn{2}{|c|}{2007} & \multicolumn{2}{|c|}{2008} \\
\hline & USD & $\%$ & USD & $\%$ & USD & $\%$ & USD & $\%$ & USD & $\%$ & USD & $\%$ \\
\hline Total FDI stock & 12.4 & 100.0 & 21.9 & 100.0 & 23.7 & 100.0 & 33.6 & 100.0 & - & - & - & - \\
\hline Total FDI stock in services & - & - & 10.1 & 46.1 & 10.2 & 43.0 & 13.5 & 40.2 & - & - & - & - \\
\hline $\begin{array}{l}\text { FDI stock in pollution- } \\
\text { intensive services } \\
\text { a) }\end{array}$ & - & - & 0.2 & 0.9 & 0.2 & 0.8 & 0.3 & 0.9 & - & - & - & - \\
\hline
\end{tabular}

a) Hotels and restaurants, land and air transport.

Source. The OECD data base and own calculations. 


\section{References}

Budnikowski A. (1998), Ochrona środowiska jako problem globalny, PWE, Warszawa

Fortanier F., Maher M. (2001), Foreign Direct Investment and Sustainable Development, OECD Paper, [in:] New Horizons and Policy Challenges for Foreign Direct Investment in the $21^{\text {st }}$ Century, OECD Global Forum on International Investment, Mexico

Gentry B. G. (1999), Foreign Direct Investment and the Environment: Bon or Bane, [in:] Foreign Direct Investment and the Environment, OECD Proceedings, Paris

Goldenman G. (1999), The Environmental Implications of Foreign Direct Investment: Policy and Institutional Issues, [in:] Foreign Direct Investment and the Environment, OECD Proceedings, Paris

Gray K. R. (2002), Foreign Direct Investment and Environmental Impacts - Is the Debate Over?, 'RECIEL' Blackwell Publishers Ltd, Oxford, Malden, No. 11 (3)

Kolstad and Xing (1998), Do Lax Environmental Regulations Attract Foreign Investment, Deparment Economics, UC Santa Barbara, Economics Working Paper: 1078, quoted from M. Petrovic-Randjelovic (2007), Foreign Direct Investment and Sustainable Development: An Analysis of the Impact of Environmental Regulations on Investment Location Decisions, 'Facta Universitatis', Serbia, Series: Economics and Organization, Vol.4, no. 2

Report London Economics (2009), 4 November

OECD (1997), quoted from M. Petrovic-Randjelovic (2007), Foreign Direct Investment and Sustainable Development: An Analysis of the Impact of Environmental Regulations on Investment Location Decisions, 'Facta Universitatis', Serbia, Series: Economics and Organization, Vol.4, no.2

OECD (1999), Summary of the conference and discussion, [in:] Foreign Direct Investment and the Environment, OECD Proceedings, Paris

M. Petrovic-Randjelovic (2007), Foreign Direct Investment and Sustainable Development: An Analysis of the Impact of Environmental Regulations on Investment Location Decisions, 'Facta Universitatis', Serbia, Series: Economics and Organization, Vol.4, no. 2

Smarzynska and Wei (2001), pollution Havens and Foreign Direct Investment: Dirty Secret or Popular Myth?, quoted from M. Petrovic-Randjelovic (2007), Foreign Direct Investment and Sustainable Development: An Analysis of the Impact of Environmental Regulations on Investment Location Decisions, 'Facta Universitatis', Serbia, Series: Economics and Organization, Vol.4, no.2

UNCTAD (1999), World Investment Report 1999. Foreign Direct Investment and the Challenge of Development, UN, New York and Geneva

Witkowska J. (2002), Foreign Direct Investment and the Environment in Transitional Economies: The Case of Poland, [in:] eds. K. Fatemi and D. Jourdan Contemporary Developments in International Business, Editions ESKA, Paris 
Witkowska J. (2007), Foreign Direct Investment in the Changing Business Environment of the European Union's New Member States, 'Global Economy Journal': Vol. 7: Issue. 4, http://bepress.com/gej/vol7/iss $4 / 2$

Wysokińska Z., Witkowska J. (2004), Handel i inwestycje zagraniczne a zrównoważony rozwój, Wydawnictwo Uniwersytetu Łódzkiego, Łódź

Zarsky (1999), Havens, Halos and Spaghetti: Untangling the Evidence about Foreign Direct Investment and the Environment, [in:] Foreign Direct Investment and the Environment, OECD Proceedings, Paris

\section{Streszczenie}

\section{BEZPOŚREDNIE INWESTYCJE ZAGRANICZNE A ZRÓWNOWAŻONY ROZWÓJ W NOWYCH KRAJACH CZLONKOWSKICH UNII EUROPEJSKIEJ. ASPEKTY OCHRONY ŚRODOWISKA}

Celem artykutu jest zbadanie potencjalnego wptywu działalności inwestorów zagranicznych na środowisko w nowych krajach cztonkowskich Unii Europejskiej (UE) oraz ocena roli wspólnej polityki ochrony środowiska UE i polityki wobec inwestorów zagranicznych w tym zakresie. Analiza obejmuje trzy nowe kraje członkowskie UE, $t j$. Czechy, Polske i Stowację. Zakres czasowy analizy to lata 1997-2007. Przedmiotem analizy jest struktura sektorowa i branżowa skumulowanych bezpośrednich inwestycji zagranicznych (BIZ) w tych krajach, ze szczególnym uwzględnieniem BIZ ulokowanych $w$ przemystach intensywnie zanieczyszczajacych środowisko. Do określenia tych przemystów wykorzystano klasyfikację UNCTAD. W analizie statystycznej wykorzystano baze danych OECD oraz statystyki narodowe. Wyniki badań wskazuja, że - jak dotychczas - nie ma empirycznych dowodów, iz BIZ maja szczególnie negatywny wpływ na środowisko w nowych krajach członkowskich UE. 